ppi $201502 Z U 4645$

Esta publicación cientifica en formato digital es continuidad de la revista impresa ISSN-Versión Impresa 0798-1406 / ISSN-Versión on line 2542-3185Depósito legal pp

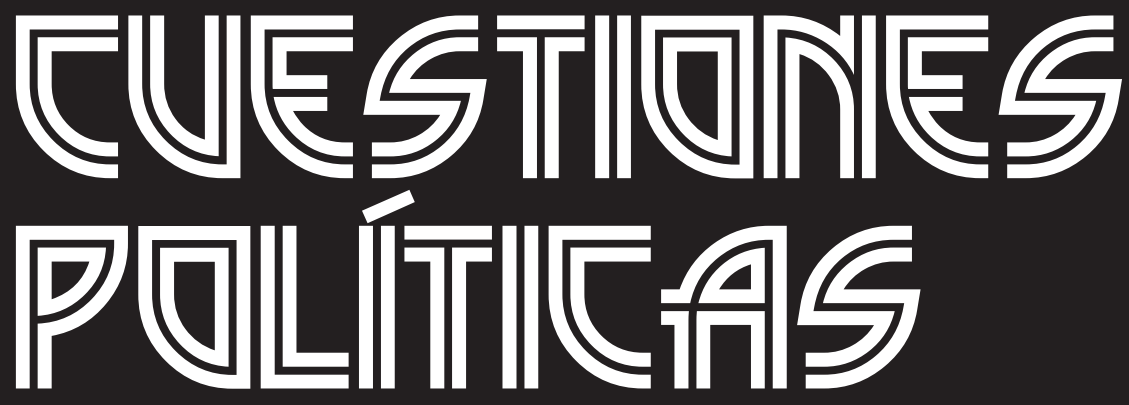

Instituto de Estudios Políticos y Derecho Público "Dr. Humberto J. La Roche' de la Facultad de Ciencias Jurídicas y Políticas de la Universidad del Zulia Maracaibo, Venezuela
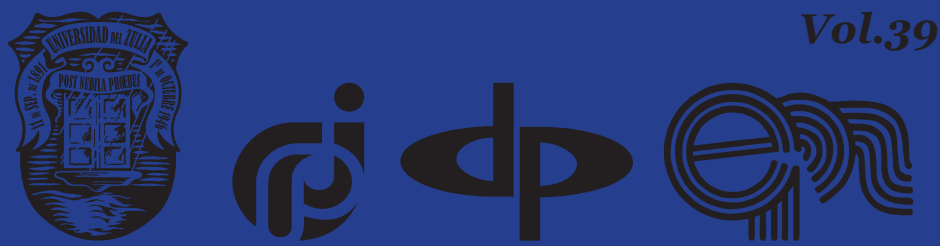


\title{
Legal Regulation of Relations on the Establishment of the Origin of Children in the Russian Federation
}

\author{
DOI: https://doi.org/10.46398/cuestpol.3968.49
}

\section{Leisan Nafisovna Khasimova * Alexey Olegovich Zadvornov **}

\begin{abstract}
The birth of a person is one of the unforgettable events in the life of each family, full of vivid emotions. From this moment on, parents assume new roles, containing moral and legal obligations in relation to the newborn. In this case, it is not important if the child's parents are legal or really married. Based on the analysis of the current family legislation of the Russian Federation and the theoretical provisions devoted to the legal regulation of the establishment of the origin of children, the article examines the mechanism of the emergence of parental legal relations, as well as a set of problems associated with their evaluation, interpretation, and application. The problems of legal regulation in the field of determining the origin of children, the prospects for the development of legislation in this area of relationships, are identified. The general methodological basis was formed by the scientific method, which allowed to consider the problems of the development of family legislation in the legal regulation to establish the origin of children in the Russian Federation. The article presents the opinions of the authors and analyses the theoretical research of scientists
\end{abstract} in this area

Keywords: kinship; rights of the child; establishment of the origin of children; birth registration; Russian federation.

Leisan Nafisovna Khasimova, Kazan Federal University. ORCID ID: https://orcid.org/oooo-00021538-1788. Email: hasimov_l@mail.ru

** Alexey Olegovich Zadvornov, Kazan Federal University. ORCID ID: https://orcid.org/oooo-ooo27829-1667. Email: a.zadvornov11@ya.ru 


\section{Reglamento jurídico de las relaciones sobre el establecimiento del origen de los niños en la Federación de Rusia}

\section{Resumen}

El nacimiento de una persona es uno de los eventos inolvidables en la vida de cada familia, lleno de vívidas emociones. A partir de este momento, los padres asumen nuevas funciones, conteniendo obligaciones morales y legales en relación con el recién nacido. En este caso, no es importante si los padres del niño están legal o realmente casados. Basado en el análisis de la legislación familiar actual de la Federación de Rusia y en las disposiciones teóricas dedicadas a la regulación legal del establecimiento del origen de los niños, el artículo examina el mecanismo del surgimiento de relaciones legales parentales, así como un conjunto de problemas asociados con su evaluación, interpretación y aplicación. Se identifican los problemas de la regulación jurídica en el campo de la determinación del origen de los niños, las perspectivas de desarrollo de la legislación en este ámbito de relaciones. La base metodológica general se formó mediante el método científico, que permitió considerar los problemas del desarrollo de la legislación familiar en la regulación legal para establecer el origen de los niños en la Federación de Rusia. El artículo presenta las opiniones de los autores y analiza la investigación teórica de los científicos en esta área.

Palabras clave: parentesco; derechos del niño; establecimiento del origen de los niños; registro de nacimiento; federación rusa.

\section{Introduction}

Establishing the origin of a child is a law-forming legal fact that gives rise to the child's personal and property rights and forms his/her legal status. It is known that a child's personality develops and improves best in a twoparent family. Family is the first and main stage of human socialization. The family is one of the main objects of study of various sciences, including legal one. However, at the legislative level, the concept of a family has not yet been developed.

In accordance with the current domestic legislation, the mutual rights and obligations of parents and children are based on the origin of children, certified in accordance with the legally established procedure, on the basis of the genetic (biological) relationship between a particular child and his/ her parents. We see the legal significance of the certificate of the child's origin in the fact that it acts as a legal guarantee of the protection of the rights of both the child himself and the rights of his parents, since parental 
legal relations between the child and his biological parents arise at the time of state registration of the establishment of the child's origin. Accordingly, parents can begin to fulfill their duties as legal representatives of the child only after formalizing their relationship with the child in the manner prescribed by law.

\section{Materials and Methods}

According to the Civil Registry Office of the Cabinet of Ministers of the Republic of Tatarstan, at the end of 2017, 48,596 newborns were registered in the Republic of Tatarstan. In Naberezhnye Chelny, the number of birth certificates was 7377, which is three times less than in Kazan, with 21,888 registered. This situation is explained, in our opinion, by a direct connection with the birth rate in the country as a whole in the 9os of the XX century, since today children born at that time become parents. In 2017, the number of registered births was less than in 2016, however, in general, over the past 10 years, the number of registered births in the capital of Tatarstan has grown by $42 \%$ (Statistical reporting on state registration of vital records in the Republic of Tatarstan at the end of 2017, 2018).

According to the data from the same source, for 2018 the civil registry authorities (hereinafter referred to as the registry office) of the Republic of Tatarstan registered 46,793 birth certificates, which is 1,803 less than in 2017 (Statistical reporting on state registration of vital records in the Republic of Tatarstan at the end of 2018, 2019).

In 2019, 43,180 birth certificates were registered, which is 3,613 less than in 2018. There was a 7.7\% decrease in births compared to 2018. However, despite the constant slight decrease in the number of births over the past three years in the Republic of Tatarstan, it is worth noting that the measures taken by the state to stimulate the birth rate have proved their effectiveness. More than 60\% of children born in 2019 are the second, third, etc. child in the family (Statistical reporting on state registration of vital records in the Republic of Tatarstan at the end of 2019, 2020).

In 2017, the registering authorities drew up 6291 paternity registration certificates. This is $10.4 \%$ less than in 2016 . According to the same source, in 2018 the civil registry offices drew up 5893 paternity registration certificates. In 2019 - 5502 certificates.

Modern conditions of development of society have caused a certain reassessment of views on the traditional family. In this regard, the legislation in the field of establishing the origin of children needs further study and improvement. The importance of studying the problems of legal regulation of relations associated with establishing the origin of children is determined by the need to ensure that the interests of the child are met. 
However, the interests of parents in this matter are no less important. After all, if a person not involved in the birth of a child carries out his upbringing and maintenance of the child, then there is a clear implementation of other people's parental rights and the fulfillment of other people's duties. And the de facto parent in this case, if the specified legislation is imperfect, can shift parental responsibilities to another person.

The procedural aspect of the considered issue also plays an important role. In a judicial procedure for establishing the origin of children, some controversial points may arise. Family law requires state registration both of the fact of birth and the fact of origin. They serve as the basis for the emergence of rights and obligations between parents and children.

The document confirming the registration of the above facts indicates information about the parents. Moreover, most often the registration of the fact of birth and the fact of origin coincide. However, the absence of a legally registered marriage between parents or other fact that reliably confirms the fact of paternity will prevent this from happening.

\section{Research results}

Parental relationship is a set of personal non-property and property relations between a child on the one hand and his father and mother, on the other. The rights and obligations of parents associated with proper maintenance, upbringing, and child care, constitute the content of these legal relations.

These relationships develop within the family and are difficult to legalize. They are based on spirituality, love, caring and respect. Each family builds them according to an individual model, based largely on the personal qualities of family members. Accordingly, the legislator cannot establish precise prescriptions for the behavior of participants in family legal relations, limiting himself only to general principles and principles. It can be argued that family relationships are the basis of state relations.

Parental relationship should be considered as an independent type of family relationship. A characteristic feature of parental relationships is the elemental composition, features of their emergence, development and termination. Their very name contains the whole essence of parental relationships - these are the rights and obligations of parents in relation to children, meanwhile, their content also includes the rights and obligations of children in relation to parents.

Parents and children are the subjects of these legal relations. The parents of the child are a woman and a man, recorded in the birth register in the registry office. In a biological sense, these are persons the child genetically originates from. 
In addition to biological origin, parents and children are interconnected by a set of mutual rights and obligations enshrined in law. From a legal standpoint, a legal connection between them arises only after the implementation of the procedure for certifying the origin of the child from specific persons.

Recently, along with the category of genetic parenting as the basis for the emergence of a legal relationship between parents and a child, the category of social parenting has been justified. This is due to the existence of such legal institutions as adoption, as well as to the active development and use of assisted methods of human reproduction. Recently, many states has shown a tendency to an increase in the use of these methods, which cannot be ignored by both fertility specialist, geneticists, sociologists, public figures, and jurists (Tagaeva and Aminova, 2017). As an example, surrogacy can be mentioned.

The domestic legislation does not provide for any adequate legal regulation of the mechanism for the use of assisted reproductive technologies (ART) and the procedure for establishing the origin of a child born with the use of ART. Only legal relations have been settled on the registration of a surrogate mother as the mother of a newborn.

The development of reproductive medicine has given rise to certain problems of legal regulation in this area. Researchers of the legal regulation of these legal relations began to operate with new categories: "reproductive travel" (Gürtin, 2011), "fertility tourism", "reproductive tourism", "medical tourism" (Inhorn and Patrizio, 2009; Letherby, 1999; Whittaker and Speier, 2010). As A. Diel rightly notes, at the international level, there are also no uniform or at least similar legal norms designed to regulate reproductive tourism that is actively flourishing in many countries (Diel, 2014).

Modern states are ambivalent about ART. In a number of countries, such as Russia, the USA, Azerbaijan, Armenia, Great Britain, Georgia, India, etc., the use of ART is permitted, and surrogacy is especially popular (Dickens and Cook, 1999). In a number of countries, surrogacy is prohibited. We are talking about such European countries as Germany, Norway, France, etc. In this regard, problems arise when using surrogacy complicated by a foreign element.

In accordance with the family legislation of the Russian Federation, parental rights and responsibilities are recognized primarily for biological parents, although there are exceptions.

Registry offices carry out state registration of the fact of the birth of a child, simultaneously confirming its origin from a certain man and woman. But what is it for? 


\section{Leisan Nafisovna Khasimova y Alexey Olegovich Zadvornov

In practice, there are cases when the lack of data on the origin of a child from a particular person may serve as an obstacle to the exercise of the subjective rights of the mother and child.

Based on the established relationship, the issues of alimony obligations between parents and children are resolved in court.

Establishment of family ties is necessary when considering certain categories of cases in the order of administrative proceedings. In one of the cases, the court found that the citizen did not submit an application for registration of his newborn daughter at his place of residence within the time limit established by law, which was recognized as a violation of the rights of the child and led to administrative liability.

An analysis of judicial practice shows that the legal registration of the fact of the child's origin from his/her parents plays a very important role in the performance of any transactions by the parents in relation to the child's property, hence the right to judicial protection of the rights of the child and his parents. Consequently, the legislator provides for the obligatory registration of the fact of birth and origin of a child within a specified period.

In the Russian Federation, the requirement established by Article 7 of the Convention on the Rights of the Child of November 20, 1989, according to which a child must be registered immediately after his/her birth, confirms his/her origin and the fact of birth. The origin of a child from specific parents is recognized as a confirmed legal fact only after it has been certified by a competent authority. With an application for the birth of a child, parents must contact the registry office within a month from the date of birth of the child, in accordance with the requirements of paragraph 6 of Art. $16 \mathrm{FZ}$ «On vital records".

Today, in most of the countries of the world, including the Russian Federation, children born both out and in wedlock have equal rights. This legal position is of fundamental importance and is established by the 1989 UN Convention «On the Rights of the Child». Also, in order to exercise the rights of children, to prevent their discrimination in the Russian Federation, the Federal Law "On the Basic Guarantees of the Rights of the Child in the Russian Federation" of July 24, 1998 No. 124-FZ was adopted. Chapter 2 of this law establishes the main directions of ensuring the rights of the child in the Russian Federation, which include legislative guarantees of the rights of the child, assistance in their implementation and protection, measures to promote the comprehensive development of the child, etc.

Despite the legally enshrined principle of equality, in fact, there is still an influence of the circumstances of the birth of a child, namely the presence of a registered marriage between his/her parents. The procedure for establishing the origin of the child from the father depends on this circumstance. 
Parental rights and responsibilities do not legally arise by themselves immediately after the birth of a child. In order to acquire parental rights and responsibilities, state registration of the fact of the birth of a child should be carried out (Krasnova, 2016). The establishment of a direct genetic, biological tie between parents and a newborn can be considered as the main legal fact within the framework of the actual composition of the creation of their legal relationship.

We think that the mechanism for establishing the origin of a child provided for by the legislator is aimed primarily at protecting the rights and interests of a minor. This mechanism also creates a legal basis for parents to exercise their rights and fulfill their responsibilities for the upbringing and maintenance of their child. After all, the formal consolidation of family relations is very important.

\section{Summary}

As mentioned above, the emergence of legal relations between a child and his parents requires two components: firstly, the very birth of the child, and secondly, the establishment of the fact of the child's origin from specific parents.

The birth of a child, as a vital record and as a legal fact of legal significance, requires mandatory state registration. As a rule, the registration of the fact of birth and the establishment of the origin of the child coincide in time, since after completing this procedure, the parents receive a birth certificate of the child, which contains information about the parents as well.

The certificate of state registration of birth (hereinafter - the birth certificate) is an official document of the state standard.

The federal law «On vital records», defining the range of sources, establishes that the legislation on vital records consists of the Federal Law based on the provisions of the Civil and Family Codes of the Russian Federation and the regulatory legal acts of the Russian Federation adopted in accordance with it. In the cases provided for by this Federal Law, when registering vital records, the norms established by the laws of the constituent entities of the Russian Federation adopted in accordance with the FC RF, in particular, the Family Code of the Republic of Tatarstan (hereinafter referred to as the FC RT), are considered.

For example, according to Art. 49 FC RT, a child can be assigned a patronymic based on national traditions. This is another regional feature of the Republic of Tatarstan, enshrined at the level of the law of the subject of the Russian Federation. 
State registration of vital records is also possible at the consular offices of the Russian Federation.

The regulatory framework on the basis of which the powers to register vital records are exercised include administrative regulations adopted by the authorized federal executive body on the basis of legislation on vital records. For example, the Order of the Ministry of Justice of Russia «On Approval of the Administrative Regulations for the Provision of State Services for State Registration of Vital Records by Bodies Carrying out State Registration of Vital Records in the Russian Federation» (hereinafter referred to as the Regulation).

In case parents, for objective reasons, are not able to independently apply to the registry office in order to register the fact of the birth of a child, in accordance with the Regulations, an authorized person can submit an application for registration on the basis of a parental power of attorney. An official of the institution the child is staying was born in has the same right.

The application must be sent within a month from the date of the actual birth of the child.

The applicant must attach to the application a birth certificate issued by the medical organization the birth took place in.

The regulations on state registration of vital records also provide for state registration of the fact of the birth of a child who was born dead.

In accordance with Art. 51 of the Investigative Committee of the Russian Federation and the aforementioned regulations, the state registration of the fact of the birth of a child born using artificial methods of reproduction, namely surrogate motherhood, is carried out. Spouses who have expressed their will in writing to bear and give birth to their child by a surrogate mother can be recorded as biological parents of the newborn only after receiving written consent from the surrogate mother.

\section{Conclusion}

Recently, the state's interest in the problems of family law has been increasing. This is due to the improvement of legal regulation of family legal relations, and with the increasing attention of the state to the problems of family, motherhood, fatherhood and childhood, which in turn is due to the need to solve social problems in society.

Registration of vital records, in general, and registration of the fact of birth in particular, is an invariable proof that the facts that require state registration have actually taken place, happened in a person's life. The final stage of state registration of the fact of birth is the issuance of a 
birth certificate by a state body, which is an official document. We see the importance of registration of vital records in streamlining civil turnover, it is aimed at protecting state interests, ensuring law and order in the country as a whole, as well as protecting the interests of individuals, protecting their property and personal non-property rights.

While state registration of the fact of birth is a certificate of the child's origin and serves as the basis for the emergence of parental relationships.

\section{Acknowledgments}

The work is performed according to the Russian Government Program of Competitive Growth of Kazan Federal University.

\section{Bibliographic References}

DICKENS, Bernard; COOK, Rebecca. 1999. "Some ethical and legal issues in assisted reproductive technology: Ethical and legal issues in reproductive health” In: International Journal of Gynecology \& Obstetrics. Vol. 1, No. 66, pp. 55-61.

DIEL, Andria. 2014. Leihmutterschaft und Reproduktions-tourismus. Frankfurt am Main Wolfgang Metzner: Verlag. Frankfurt am Main: Germany.

GÜRTIN, Zeynep B. 2011. Banning Reproductive Travel: Turkey's ART Legislation and Third-Party Assisted Reproduction. Reproductive Biomedicine. Turkey, Ankara.

INHORN, Marcia C; PATRIZIO, Pasquale. 2009. "Rethinking reproductive "tourism" as reproductive "exile" In: Fertility \&Sterility. Vol. 3, No. 92, pp. 904-906.

KRASNOVA, Tampana V. 2016. "Fathers and Sons: problems of acquiring parental rights by men (on the example of Russian legislation" In: Bulletin of Perm University. Legal sciences. Vol. 11, pp. 426-439.

LETHERBY, Gayle. 1999. "Other than mother and mothers as others: The experience of motherhood and non-motherhood in relation to 'infertility' and 'in-voluntary childlessness"' In: Women's Studies International Forum. Vol. 3, No. 22, pp. 359-372.

STATISTICAL REPORTING ON STATE REGISTRATION OF VITAL RECORDS IN THE REPUBLIC OF TATARSTAN AT THE END OF 2017. 2018. Site of the Office of Civil Status Registration of the Cabinet of Ministers of the Republic of Tatarstan. Avaliable online. In: http://zags. tatarstan.ru/. Consultation date: 22/06/2020. 
STATISTICAL REPORTING ON STATE REGISTRATION OF VITAL RECORDS IN THE REPUBLIC OF TATARSTAN AT THE END of 2018. 2019. Site of the Office of Civil Status Registration of the Cabinet of Ministers of the Republic of Tatarstan. Avaliable online. In: http://zags. tatarstan.ru/. Consultation date: 22/06/2020.

STATISTICALREPORTINGONSTATEREGISTRATIONOFVITALRECORDS IN THE REPUBLIC OF TATARSTAN AT THE END of 2019. 2020 Site of the Office of Civil Status Registration of the Cabinet of Ministers of the Republic of Tatarstan. Avaliable online. In: https://zags.tatarstan.ru/ statisticheskie-dannie.htm. Consultation date: 22/06/2020.

TAGAEVA, Samouel; AMINOVA, Farida. 2017. "Problems of the application of law and order to the complicated «foreign element» relations arising from assisted reproductive technologies" In. Bulletin of Perm University. Legal sciences. No. 36, pp. 192-202.

WHITTAKER, Andrea; SPEIER, Amy. 2010. "Cycling overseas": care, commodification and stratification in cross-border reproductive travel" In: MedicalAn-thropology. Vol. 4, No. 29, pp. 363-383. 

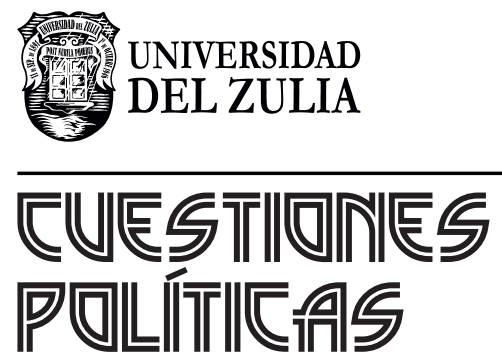

Vol.39 No 68

Esta revista fue editada en formato digital y publicada en enero de 2021, por el Fondo Editorial Serbiluz, Universidad del Zulia. Maracaibo-Venezuela 